\title{
THE CONTENT OF POLYCHLORINATED HYDROCARBONS IN ARCTIC ECOSYSTEMS
}

\author{
Jørgen Clausen and Ole Berg
}

Institute of Hygiene, Social and Preventive Medicine and Environmental

Science, Odense University, and from Institute of Hygiene, University of Copenhagen, Denmark

\begin{abstract}
The content of polychlorinated hydrocarbons (PCHC) (mainly pesticides and their metabolites) and polychlorinated biphenyls (PCB) were assayed in fat tissue specimens of hunting animals, shot on the southwest coast of Greenland, and in Eskimoes of the same area.

Among the birds highest amounts of $p p^{\prime} \mathrm{DDE}$ and PCB were found in the cormorant and the raven (high amounts of PCB were also found in the Brünnich's Guillemot), $p p^{\prime}$ DDT and $p p^{\prime}$ DDP were not traced.

Among the mammals shot the polar bear contained highest amounts of PCB, but also the common porpoise showed high values. Great individual variations, however, occurred. The mammals all contained relatively low amounts of $p p^{\prime} \mathrm{DDE}$ when the data were compared to the bird species studied.

Female Eskimoes showed a PCB content of fat tissue equal to that found in the fat tissue of mammals, but lower than the PCB content in the birds.
\end{abstract}

\section{INTRODUCTION}

The use of chlorinated pesticides for more than 30 years and of polychlorinated biphenyls (PCB) for more than 40 years has caused a worldwide accumulation of these components in different ecosystems ${ }^{1-9}$. Our recent studies of the content of polychlorinated hydrocarbons (PCHC) in Arctic ecosystems of Greenland ${ }^{10,11}$ and the present study were designed to compare the concentration of PCHC in Arctic animals to the content of these components in Greenlanders. Greenlanders are mainly hunters and fishermen, which is of interest since food caught locally forms a major part of their diet and they may, thus, be affected by PCHC accumulated in the food chains.

\section{Materials}

\section{MATERIALS AND METHODS}

Adipose tissue from animals shot on the west coast of Greenland (from Narssarssuaq in the south to Sukkertoppen in the north) was taken mainly from the back, sealed in glass tubes and air mailed to Copenhagen for assay. The present communication reports the assay of PCHC in fat tissue of two common porpoises (Phocaena phocaena), five bearded seals (Erignathus barbatus), five ringed seals (Phoca hispida), five hooded seals (Cystophora cristata), two arctic foxes (Alopex lagopus), one polar bear (Ursus maritimus), and one sheep (Ovis aries). Studies were also made on adipose tissue taken 
from the neck of the king eider (Somateria spectabilis), the common eider (Somateria mollissima), the harlequin duck (Histrionicus histrionicus), the long tailed duck (Glangula hyemalis), the purple sandpiper (Calidris maritima), Brünnich's guillemot (Uria lomvia), the cormorant (Phalocrocorax carbo), the ptarmigan (Lagopus mutus) and the raven (Corvus corax). Finally, subcutaneous adipose tissue was taken operatively from six Greenlanders. These patients were hospitalized due to non-malignant acute diseases. They were all women aged from 26 to 57 years.

\section{Standards}

The standards are as follows : Standards of PCHC: Heptachlor $(1,4,5,6,7,8,8-$ heptachloro-3 $\alpha, 4,7,7 \alpha$-tetrahydro-4,7-methanoindene) and heptachloroepoxide (Riedel, De Haën AG, Seelze-Hannover, W. Germany), Lindane (1,2,3,4,5,6-hexachlorocyclohexane), $o p^{\prime}$ DDT, $p p^{\prime}$ DDT (1,1,1-trichloro-2,2bis(p-chlorophenyl)ethane) and $p p^{\prime} \mathrm{DDE}$ [1,1-bis(4-chlorophenyl)-2,2-dichloroethylene] (Ferrosan, Copenhagen, Denmark), Aldrin (1,2,3,4,10,10hexachloro-1,4,4 $\alpha, 5,8,8 \alpha$-hexahydro-endo,exo-1,4:5,8-dimethanonaphthalene) and Dieldrin $(1,2,3,4,10,10$-hexachloro-6,7-epoxy-1,4,4 $\alpha, 5,6,7,8,8 \alpha$-octahydro-endo,exo-1,4:5,8-dimethanonaphthalene)(Shell Research Ltd, Sittingbourne, Kent, UK), polychlorinated biphenyls (PCB) (Aroclor 1254, 12 carbon atoms and $54 \%$ chlorination) (Monsanto, St Louis, Missouri, USA).

\section{Reagents}

The reagents were $n$-hexane (b.pt $67-70^{\circ}$ ) distilled once or twice over sodium hydroxide pellets with a Vigreux column. $\mathrm{Al}_{2} \mathrm{O}_{3}$ (Brockmann activity II), was from BDH, Poole Dorset, UK. Acetone p.a. redistilled with $1 \mathrm{~m}$ Vigreux column, and sodium sulphate anhydrous (p.a.) were from Merck, Darmstadt, Germany. When concentrated 20 times, $10 \mu \mathrm{l}$ of any solvent used did not reveal PCHC peaks when assayed in the gas chromatograph. Glass wool and glassware were rinsed in petrol-ether.

\section{Methods}

Gas chromatography $(G L C)$

Model Perkin Elmer F 11 with a ${ }^{63} \mathrm{Ni}$ electron capture detector and a borosilicate glass column $(3 \mathrm{~mm}$ i.d. $\times 2 \mathrm{~m})$, packed with a mixture of $5 \%$ Dow $200(12500 \mathrm{cts})$ and $7 \frac{1}{2} \% \mathrm{QF}_{1}(10000 \mathrm{cts})(1+1)$ on Chromosorb G. The column was conditioned at $250^{\circ}$ for one week in order to avoid the $\mathrm{QF}_{1}$ bleeding, and working conditions were as described by Delvaux ${ }^{12}$ with the exception of better separation at $180^{\circ}$ column temperature than at $200^{\circ}$ (injection temp. $220^{\circ}$, detector temp. $220^{\circ}$ ). Carrier gas : nitrogen at flowrate of $60-70 \mathrm{ml} / \mathrm{min}$; detector supply $\frac{2}{3}$ of maximal current. Sensitivity: $1 \mathrm{ng}$ heptachloroepoxide gave $50 \%$ of full scale. A Micro-Snyder evaporative concentrator was used and for thin layer chromatography (TLC) Desaga Werke equipment (W. Germany) was used.

\section{Extraction}

About $400 \mathrm{mg}$ adipose tissue was extracted twice, each with $7 \mathrm{ml} n$-hexane at $22^{\circ}$ for $1 \mathrm{~h}$ and once overnight at $22^{\circ}$. Re-extraction with petrol-ether, 
chloroform :methanol $(1: 1)$, acetonitrile or acetone :hexane $(1: 1)$ revealed the remaining $\mathrm{PCHC}$ to be less than two per cent of the original content.

\section{Clean up}

Raw extract was dried over sodium sulphate and concentrated under a stream of nitrogen at room temperature. The PCHC were weighed and dissolved in $n$-hexane to a concentration of about $100 \mathrm{mg} / \mathrm{ml} .1 \mathrm{ml}$ of the extract was separated from lipids by the single stage method $^{3}$. To a column of $2 \mathrm{~g}$ alumina, activated to $\mathrm{Al}_{2} \mathrm{O}_{3}$ at $800^{\circ}$ for $4 \mathrm{~h}$, cooled and supplied with $5 \%(\mathrm{v} / \mathrm{v})$ of water, the lipid extract in hexane was added at the top. After $5 \mathrm{~min}, 1 \mathrm{ml}$ of hexane was applied and the column was eluted with a further $10 \mathrm{ml}$ of $n$-hexane.

This eluate was reduced to $1 \mathrm{ml}$ at $23^{\circ}$ in a gentle stream of nitrogen. The column chromatography of this eluate was repeated. The final eluate, reduced to about $0.5 \mathrm{ml}$, was assayed in the gas chromatograph using 1-10 $\mu$ l samples. By repeating the assay on the solvents without the sample, no PCHC peaks were found. Recovery was 80-100 per cent for Lindane, Heptachlor, heptachloroepoxide, Aldrin, $p p^{\prime} \mathrm{DDE}$, Dieldrin and $p p^{\prime} \mathrm{DDT}$. Lindane and Aldrin were determined on the chromatogram obtained after the clean-up procedure. At this stage, raw $p p^{\prime} \mathrm{DDE}$ ( $p p^{\prime} \mathrm{DDE}$ plus PCB) was also determined together with PCB, by combining the products obtained by multiplying the height of individual peaks with the corresponding retention time of $1 \mathrm{ng} p p^{\prime} \mathrm{DDE}^{2}$. For identification purposes spots of pesticides on the TLC (vide infra) were scraped off, eluted with $5 \mathrm{ml}$ of hexane and determined by GLC.

\section{Thin-layer chromatography}

TLC was performed on $0.25 \mathrm{~mm}$ aluminium oxide G (type E). $20 \mu \mathrm{l}$ of concentrated, de-lipidized PCHC extract from the alumina column was applied on the TLC plates $1.5 \mathrm{~cm}$ from the lower edge and developed in an ascending system with $1 \%(\mathrm{v} / \mathrm{v})$ acetone in normal hexane for $15 \mathrm{~min}$. The pattern of standard markers on the TLC plates was sprayed with $0.10 \mathrm{~g}$ $\mathrm{AgNO}_{3}$ dissolved in $1 \mathrm{ml}$ water and $10 \mathrm{ml}$ concentrated 2-phenoxyethanol ${ }^{10}$. The solution was diluted to $200 \mathrm{ml}$ with acetone and 5 drops of 30 per cent hydrogen peroxide were added. The spots of markers localized the sample spots (identified by their $R_{\mathrm{f}}$-values). The sample spots were scraped off, eluted in hexane and re-chromatographed.

\section{Statistical evaluation}

Since the data presented below showed a non-Gaussian distribution the non-parametric, nominal Fisher test was used in order to evaluate the data obtained on the different species. The limit for comparison of data was chosen as arithmetic mean between the highest value in the species having lowest mean value, and the lowest value in the species showing the highest mean value. The level of significance was selected at the one per cent level. Correlation analysis was performed by the Spearman Rank test. 


\section{RESULTS}

Table 1 shows the PCHC content in adipose tissue of birds shot in 1972 on the West Coast of Greenland.

The birds showing the lowest (mean) concentration of raw $p p^{\prime} \mathrm{DDE}$ were the king eider (mean : 1.7 p.p.m.), the common eider (0.8 p.p.m.), the harlequin

Table 1. The content of chlorinated organic components in fat tissue of Arctic birds from Greenland. (p.p.m. dry weight)

\begin{tabular}{|c|c|c|c|c|}
\hline Species & Sample No. & $p p^{\prime} \mathrm{DDE} \uparrow$ & РCB & Lindane $\S$ \\
\hline King eider (Somateria spectabilis) & $\begin{array}{r}166 \\
82 \\
119\end{array}$ & $\begin{array}{l}1.1 \\
2.6 \\
1.3\end{array}$ & $\begin{array}{l}1.1 \\
5.3 \\
3.5\end{array}$ & $\begin{array}{c}\text { n.d. } \ddagger \\
\bar{T} \\
0.02\end{array}$ \\
\hline Eider duck (Somateria mollissima) & 68 & 0.8 & 2.0 & 0.12 \\
\hline Harlequin duck (Histrionicus histrionicus) & $\begin{array}{r}79 \\
110 \\
109 \\
42 \\
41\end{array}$ & $\begin{array}{l}1.1 \\
1.1 \\
1.2 \\
0.7 \\
1.2\end{array}$ & $\begin{array}{l}2.2 \\
3.2 \\
4.6 \\
2.9 \\
4.8\end{array}$ & $\begin{array}{l}\text { n.d. } \\
0.08 \\
\text { n.d. } \\
- \\
-\end{array}$ \\
\hline Long tailed duck (Clangula hyemalis) & $\begin{array}{l}84 \\
51 \\
80\end{array}$ & $\begin{array}{l}1.3 \\
1.0 \\
0.8\end{array}$ & $\begin{array}{l}4.1 \\
6.0 \\
2.9\end{array}$ & $\begin{array}{c}\overline{0.06} \\
-\end{array}$ \\
\hline Purple sandpiper (Calidris maritima) & 112 & 1.1 & 2.8 & 0.04 \\
\hline Brünnich’s guillemot (Uria lomvia) & $\begin{array}{r}17 \\
4 \\
3 \\
5 \\
18\end{array}$ & $\begin{array}{l}3.6 \\
8.7 \\
2.4 \\
1.8 \\
1.2\end{array}$ & $\begin{array}{r}8.5 \\
39.6 \\
6.3 \\
6.2 \\
3.9\end{array}$ & $\begin{array}{c}\text { n.d. } \\
\overline{-} \\
0.31 \\
-\end{array}$ \\
\hline Cormorant (Phalocrocorax carbo) & $\begin{array}{l}71 \\
72 \\
74\end{array}$ & $\begin{array}{r}15.0 \\
6.5 \\
9.5\end{array}$ & $\begin{array}{l}46.7 \\
18.0 \\
14.1\end{array}$ & - \\
\hline Ptarmigan (Lagopus mutus) & $\begin{array}{l}121 \\
120 \\
125 \\
126 \\
124\end{array}$ & $\begin{array}{l}3.6 \\
4.0 \\
3.0 \\
1.9 \\
3.9\end{array}$ & $\begin{array}{r}9.1 \\
11.1 \\
12.0 \\
2.9 \\
15.8\end{array}$ & $\begin{array}{l}\text { n.d. } \\
0.11 \\
0.40 \\
\text { n.d. } \\
0.18\end{array}$ \\
\hline Raven (Corvus corax) & $\begin{array}{r}101 \\
50 \\
114\end{array}$ & $\begin{array}{r}16.4 \\
6.5 \\
18.8\end{array}$ & $\begin{array}{l}34.6 \\
13.8 \\
63.0\end{array}$ & $\begin{array}{l}0.18 \\
\text { n.d. } \\
\text { n.d. }\end{array}$ \\
\hline
\end{tabular}

$\dagger p p^{\prime}$ DDE represents the so-called 'raw value' including some PCB.

$\ddagger$ signifies not detectable.

$\S$ identified as a fraction in GLC, which possesses an $\boldsymbol{R}_{\boldsymbol{f}}$-value of standard Lindane.

duck (1.1 p.p.m.) and the purple sandpiper (1.1 p.p.m.). However, the content was higher in Brünnich's guillemot (3.5 p.p.m.) and the ptarmigan (3.3 p.p.m.), while the highest concentrations were found in the cormorant (10.3 p.p.m.) and the raven (13.9 p.p.m.). However, in all these animals great individual variations occurred. 


\section{CONTENT OF POLYCHLORINATED HYDROCARBONS}

In the case of PCB, the lowest concentration (mean values) was found also in the group of ducks, the figures being 3.3 p.p.m. for the king eider, 2.0 p.p.m. for the common eider, 3.5 p.p.m. for the harlequin duck and 4.3 p.p.m. for the long tailed duck. In this group, the purple sandpiper (2.8 p.p.m.) may be included. For the other species mentioned, Table 1 demonstrates higher concentrations of PCB in their fat tissue, the ptarmigan containing 10.2 p.p.m., Brünnich's guillemot 12.9 p.p.m., the cormorant 26.3 p.p.m. and the raven 37.1 p.p.m., but great individual variations occurred.

$p p^{\prime}$ DDT and $p p^{\prime}$ DDD [1,1-dichloro-2,2-bis( $p$-chlorophenyl)ethane] were not traced. Dieldrin was probably present in minor amounts, although no attempt was made in the present assay to determine the exact figure since the peak could not be resolved from a PCB peak in the present GLC system. In

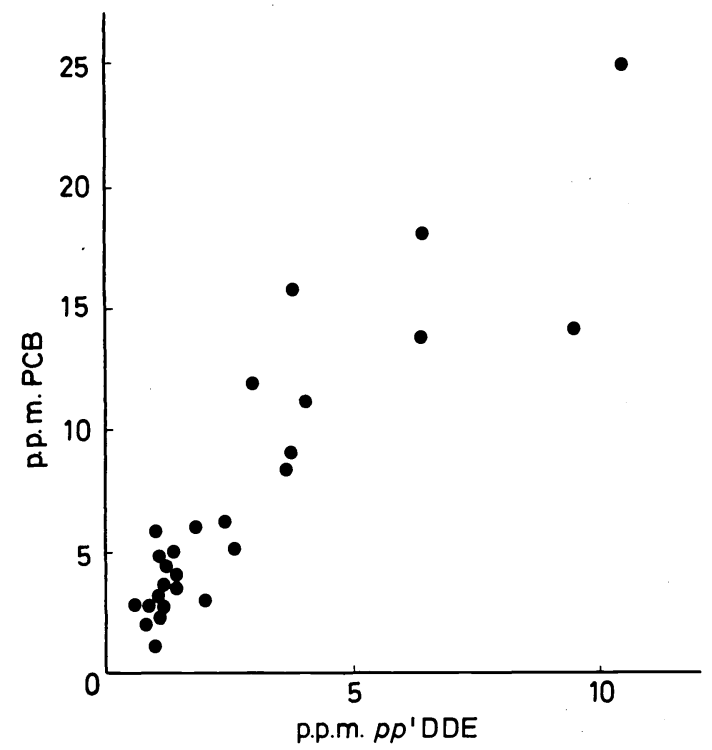

Figure 1. Correlation between 'raw' $\mathrm{pp}$ ' DDE and PCB found in avian tissue.

about one third of the birds, trace amounts of Lindane were found. Correlation analysis (Figure 1) revealed a statistically significant correlation in the studied birds between the $p p^{\prime} \mathrm{DDE}$ content and the PCB content (coefficient of correlation $0.9 ; p^{\prime}=0.1$ per cent).

Table 2 shows the PCHC content of the adipose tissues of some Arctic mammals killed in 1972 on the West Coast of Greenland. Among the PCHC studied PCBs occurred in highest amounts. The polar bear contained absolutely the highest amount (21.0 p.p.m.). Among the whales the maximum value was found in the common porpoise (Case No. 181, 11.4 p.p.m.). Among the hooded seals assayed the peak value for PCB was 4.9 p.p.m.

Among all the species studied great variations in data occurred from sample to sample. With three individual exceptions, raw $p p^{\prime} \mathrm{DDE}$ occurred in the second highest concentration among the PCHC assayed. Thus the polar bear contained the highest amount (mean value 1.25 p.p.m.) followed by the bearded seal (mean value 0.47 p.p.m.) and the common porpoise (mean 


\section{JØRGEN CLAUSEN AND OLE BERG}

Table 2. Content of polychlorinated hydrocarbons in fat tissue of Arctic mammals (p.p.m.)*

\begin{tabular}{|c|c|c|c|c|c|c|c|}
\hline Species & $\begin{array}{l}\text { Sample } \\
\text { No. }\end{array}$ & $\begin{array}{l}\text { Lindane } \\
\S\end{array}$ & $\begin{array}{l}\text { Hepta- } \\
\text { chlor }\end{array}$ & Aldrin & $\begin{array}{l}\text { Heptachloro- } \\
\text { epoxide }\end{array}$ & $\begin{array}{l}\text { 'raw' } \\
p p^{\prime} \mathrm{DDE}\end{array}$ & PCB \\
\hline $\begin{array}{l}\text { Bearded seal } \\
\quad \text { (Erignatus barbatus) }\end{array}$ & $\begin{array}{r}35 \\
29 \\
8 \\
7 \\
170\end{array}$ & $\begin{array}{l}0.037 \\
0.064 \\
0.14 \\
0.019 \\
0.007\end{array}$ & $\begin{array}{c}0.039 \\
\text { n.d. } \ddagger \\
\text { n.d. } \\
0.017 \\
\text { n.d. }\end{array}$ & $\begin{array}{l}0.12 \\
0.43 \\
1.60 \\
0.042 \\
0.029\end{array}$ & $\begin{array}{c}0.12 \\
\text { n.d. } \\
\text { n.d. } \\
0.045 \\
0.022\end{array}$ & $\begin{array}{l}0.42 \\
0.67 \\
0.80 \\
0.24 \\
0.20\end{array}$ & $\begin{array}{l}2.6 \\
0.6 \\
1.6 \\
3.0 \\
1.2\end{array}$ \\
\hline Mean values & & 0.053 & 0.011 & 0.44 & 0.037 & 0.47 & 1.8 \\
\hline $\begin{array}{l}\text { Ringed seal (Phoca } \\
\text { hispida) }\end{array}$ & $\begin{array}{r}97 \\
96 \\
30 \\
158 \\
159\end{array}$ & $\begin{array}{c}0.002 \\
0.005 \\
0.025 \\
\text { n.d. } \\
\text { n.d. }\end{array}$ & $\begin{array}{c}\text { 0.003 } \\
\text { n.d. } \\
\text { n.d. } \\
\text { n.d. } \\
\text { n.d. }\end{array}$ & $\begin{array}{l}0.008 \\
0.020 \\
0.14 \\
0.025 \\
0.025\end{array}$ & $\begin{array}{l}0.005 \\
0.021 \\
0.050 \\
0.025 \\
0.028\end{array}$ & $\begin{array}{l}0.025 \\
0.083 \\
0.26 \\
0.20 \\
0.20\end{array}$ & $\begin{array}{l}1.0 \\
1.3 \\
0.6 \\
0.7 \\
0.9\end{array}$ \\
\hline Mean values & & 0.006 & 0.001 & 0.044 & 0.026 & 0.15 & 0.9 \\
\hline $\begin{array}{l}\text { Hooded seal } \\
\text { (Cystophora } \\
\text { cristata) }\end{array}$ & $\begin{array}{l}179 \\
180 \\
183 \\
175 \\
178\end{array}$ & $\begin{array}{c}\text { n.d. } \\
0.017 \\
\text { n.d. } \\
\text { n.d. } \\
\text { n.d. }\end{array}$ & $\begin{array}{l}\text { n.d. } \\
\text { n.d. } \\
\text { n.d. } \\
\text { n.d. } \\
\text { n.d. }\end{array}$ & $\begin{array}{l}0.015 \\
0.037 \\
0.029 \\
0.024 \\
0.035\end{array}$ & $\begin{array}{c}0.058 \\
0.073 \\
0.062 \\
0.012 \\
\text { n.d. }\end{array}$ & $\begin{array}{l}0.43 \\
0.49 \\
0.31 \\
0.069 \\
0.14\end{array}$ & $\begin{array}{l}4.1 \\
2.5 \\
1.9 \\
4.9 \\
0.3\end{array}$ \\
\hline Mean values & & 0.003 & n.d. & 0.028 & 0.041 & 0.29 & 2.7 \\
\hline $\begin{array}{l}\text { Common porpoise } \\
\quad(\text { Phocaena phocaena })\end{array}$ & $\begin{array}{l}182 \\
181\end{array}$ & $\begin{array}{l}0.005 \\
0.018\end{array}$ & $\begin{array}{l}\text { n.d. } \\
\text { n.d. }\end{array}$ & $\begin{array}{l}0.043 \\
0.028\end{array}$ & $\begin{array}{r}\text { n.d. } \\
0.059\end{array}$ & $\begin{array}{l}0.045 \\
0.60\end{array}$ & $\begin{array}{r}1.9 \\
11.4\end{array}$ \\
\hline Mean values & & 0.012 & n.d. & 0.036 & 0.030 & 0.32 & 6.7 \\
\hline $\begin{array}{l}\text { Polar bear } \\
\text { (Ursus maritimus) }\end{array}$ & & n.d. & n.d. & 3.06 & 0.49 & 1.25 & 2.1 .0 \\
\hline $\begin{array}{l}\text { Arctic fox } \\
\quad \text { (Alopex lagopus) }\end{array}$ & $\begin{array}{l}91 \\
95\end{array}$ & $\begin{array}{c}0.019 \\
\text { n.d. }\end{array}$ & $\begin{array}{l}\text { n.d. } \\
\text { n.d. }\end{array}$ & $\begin{array}{l}0.043 \\
0.032\end{array}$ & $\begin{array}{l}0.047 \\
0.080\end{array}$ & $\begin{array}{l}0.22 \\
0.052\end{array}$ & $\begin{array}{l}1.6 \\
3.9\end{array}$ \\
\hline Mean values & & 0.010 & n.d. & 0.038 & 0.064 & 0.14 & 2.8 \\
\hline Sheep (Ovis aries) & 3 & n.d. & n.d. & 0.41 & n.d. & 0.19 & 1.2 \\
\hline
\end{tabular}

* cf. footnotes to Table 1 .

value 0.32 ). There were three single cases, a bearded seal, a sheep, and a polar bear where the concentration of Aldrin exceeded that of $p p^{\prime} \mathrm{DDE}$, the values for the former being $1.60,0.41$ and 3.06 p.p.m., respectively.

Lindane was found in all bearded seals (mean value 0.053 p.p.m.) and in the two cases of common porpoise studied, but only in 60 per cent of the ringed seals studied. Lindane was not found in the polar bear or in the hooded seal. Furthermore, heptachlor was rarely found, but small amounts of heptachlorepoxide were found in all but five samples.

The total content of all the components studied was found to be lowest in the sheep where only Aldrin, $p p^{\prime} \mathrm{DDE}$ and PCB could be traced. Aldrin was, 


\section{CONTENT OF POLYCHLORINATED HYDROCARBONS}

however, found in medium concentrations, when compared to the findings from the other animals under study.

Only the PCB contents of the ringed seal and the sheep were significantly lower than that of the hooded seal $(p \leqslant 0.01)$.

No correlation between raw $p p^{\prime} \mathrm{DDE}$ and the PCB content of the mammals studied could be found.

Table 3 shows the PCHC content of the human adipose tissue of the six women under study. The highest content of PCB was found in F.S. and U.A. (5.6 p.p.m. and 2.5 p.p.m., respectively) both of whom were born before the

Table 3. PCHC content of human adipose tissue from six Greenland women

\begin{tabular}{lcccccccc}
\hline Name & No. & Age & $\begin{array}{c}\text { Lindane } \\
\text { p.p.m. }\end{array}$ & $\begin{array}{c}\text { Heptachlor } \\
\text { p.p.m. }\end{array}$ & $\begin{array}{l}\text { Aldrin } \\
\text { p.p.m. }\end{array}$ & $\begin{array}{l}\text { Heptachloro- } \\
\text { epoxid,p.p.m. }\end{array}$ & p.p.m. & $\begin{array}{c}\text { PCB } \\
\text { p.p.m. }\end{array}$ \\
\hline K.F. & 209 & 26 & 0.02 & 0.04 & 0.04 & 0.03 & 0.52 & 1.02 \\
F.S. & 210 & 57 & 0.02 & 0.03 & 0.05 & 0.09 & 0.39 & 5.58 \\
E.K. & 211 & 49 & 0.003 & 0.002 & 0.003 & 0.001 & 0.04 & 0.44 \\
U.A. & 212 & 52 & 0.02 & - & 0.02 & 0.05 & 0.61 & 2.46 \\
P.P. & 213 & 28 & 0.009 & 0.006 & 0.007 & 0.02 & 0.12 & 0.90 \\
T.K. & 214 & 27 & & & 0.02 & & 0.33 & 0.25 \\
\hline
\end{tabular}

'thirties, the period in which the use of PCB was initiated. Since they both stayed in Greenland all their lives, they have thus both been exposed to PCB at the level encountered in Greenland. The content of $p p^{\prime} \mathrm{DDE}$ was within the limits of 0.12 and 0.61 p.p.m., and showed no age dependence. The other fractions of PCHC were found only in trace amounts in human adipose tissue.

\section{DISCUSSION}

Although Holden ${ }^{13}$ found small amounts of Dieldrin, DDE, TDE and DDT in one ringed seal shot on Baffin Island (Canada), little is known about the distribution of the compounds in the Arctic. The present communication revealed some of these components and PCB to be present in most samples of sea birds inhabiting the coastlines of southwest Greenland.

The amounts of PCHC present in the birds vary from one species to another. The reason for this would appear to be differences in age, dietary habits and possibly, winter migration to more heavily polluted areas of the world.

Table 4 shows the dietary habits of the birds, the type of fish or vegetable matter consumed and the probable migratory quarters.

From the results of the present communication, it seems possible that the pesticide level is more influenced by the position of the bird in the food chain than by its migratory habits. This point is demonstrated by the fact that Brünnich's guillemot, living on a diet of marine invertebrates and fish ${ }^{14}$ and migrating to the coast of Newfoundland, has a mean concentration of 'raw' $p p^{\prime} \mathrm{DDE}$ which is only 3.5 p.p.m., while the cormorant, which is preferably living on fish and is non-migratory, has a mean content of 10.3 p.p.m. of 'raw' $p p^{\prime} \mathrm{DDE}$.

The rather large concentration of pesticides found in the ptarmigan is 
difficult to explain as the birds feed on plant matter, berries and occasionally insects. They are non-migratory.

However, within the species, there are great variances in the pesticide content (cf. Table 4). This variance has also previously been described in seals $^{13}$ and birds ${ }^{7}$, and is probably related to the age and to the amount of fat tissue of the animals.

In the case of 'raw' $p p$ 'DDE, the ducks, all feeding on marine invertebrates, showed the lowest figures. The long tailed duck and the common eider are

Table 4. Dietary and migratory habits of Arctic birds

\begin{tabular}{|c|c|c|}
\hline Species & Dietary habits & Migratory habits \\
\hline $\begin{array}{l}\text { King eider } \\
\text { (Somateria spectabilis) }\end{array}$ & $\begin{array}{l}\text { Marine invertebrates, berries } \\
\text { and buds }\end{array}$ & North Atlantic Continent \\
\hline $\begin{array}{l}\text { Harlequin duck } \\
\text { (Histrionicus histrionicus) }\end{array}$ & Marine invertebrates & Non-migratory \\
\hline $\begin{array}{l}\text { Long tailed duck } \\
\text { (Glangula hyemalis) }\end{array}$ & Marine invertebrates & Western Europe \\
\hline $\begin{array}{l}\text { Purple sandpiper } \\
\text { (Calidris maritima) }\end{array}$ & Small crustaceans, insects & Northwest Europe \\
\hline $\begin{array}{l}\text { Brünnich's guillemot } \\
\text { (Uria lomvia) }\end{array}$ & Fish, marine invertebrates & $\begin{array}{l}\text { Migrates down coastline } \\
\text { towards Newfoundland }\end{array}$ \\
\hline $\begin{array}{l}\text { Cormorant } \\
\text { (Phalocrocorax carbo) }\end{array}$ & Fish & Coastal bird \\
\hline Ptarmigan (Lagopus mutus) & $\begin{array}{l}\text { Tundra vegetation, berries, } \\
\text { some insects }\end{array}$ & Non-migratory \\
\hline Raven (Corvus corax) & $\begin{array}{l}\text { Scavenger (fish in winter, } \\
\text { garbage from humans) }\end{array}$ & Coastal bird \\
\hline
\end{tabular}

migratory birds. The greatest concentration was found in the raven, a scavenger living on fish in the summer, supplemented by human refuse in the winter. This species is non-migratory.

The origin of PCHC found in the Arctic sea birds may be fish or algae, which absorb PCHC from polluted Gulf Stream water. Finally, global air pollution cannot be ruled out as a source of pesticides, since many PCHC are rather volatile.

The biological impact of PCHC on Arctic ecosystems may be serious since DDT not only decreases eggshell calcium ${ }^{15}$, but also hampers the temperature acclimatization of fish ${ }^{16,17}$, ATP-ase-activity ${ }^{18}$ and finally alters the species composition of algae ${ }^{19}$.

The DDE found may be formed in the Arctic animals or algae ${ }^{20}$ or in the ecosystems of higher temperature areas from $p p^{\prime}$ DDT.

The significant correlation found between the content of PCB and DDE in the fat tissue of the studied birds may be explained by the high ecological level of the birds and lipid solubilities of the two globally distributed PCHCs under study and their metabolic inertness ${ }^{21}$.

The PCB content in seals living in waters close to industrial areas (1.5-16 p.p.m.). $\mathrm{PCB}^{4}$ is similar to the $\mathrm{PCB}$ content of the Arctic sea mammals found in the present communication (0.025-6.85 p.p.m.). On the other hand, raw 
$p p^{\prime} \mathrm{DDE}$ occurs in lower amounts in the Arctic than in Swedish waters ${ }^{4}$. However, within the species itself there are great variations in the PCHC content. The variation in seals ${ }^{13}$ and in birds ${ }^{7}$ has previously been described and is probably related to the age and amount of fat tissue of the animals.

Contrary to our findings in the Arctic birds there is no correlation between the raw DDE content and the content of PCB in the individual mammals studied. This is in favour of the idea that seals may be able, to a greater extent than birds, to metabolize some PCHC (vide infra).

The content of raw $p p^{\prime} \mathrm{DDE}$ is about one order of magnitude lower in the Arctic mammals than in the sea birds. As far as the seals are concerned this difference is difficult to explain since seals eat fish as do many Arctic sea birds in which the PCHC content is dependent on the ecological level of the individual Arctic bird species. However, the reason may be that seals degradate and excrete more of the dietary PCHC than sea birds do. The seals along the coastline of Greenland seem to migrate periodically, but they may to a lesser extent be exposed to polluted seaways than sea birds do $^{22}$.

The present communication revealed the Arctic sheep to have a low PCHC content, explainable by its diet being exclusively of plant origin. By contrast, the Arctic fox being a scavenger contained high amounts of PCB and Lindane but lower amounts of raw $p p^{\prime} \mathrm{DDE}$.

In comparing the PCB content of the human adipose tissue to that of the animals shot in Greenland, Greenlanders seem to contain equal amounts or more PCB than most Arctic mammals. The PCB content in Greenlanders was found to be highest in the oldest individuals, corresponding to the longest time of accumulation. The human adipose tissue contained less $p p^{\prime} \mathrm{DDE}$ than that of the birds but the amounts were comparable to those of the seals.

The relatively high PCB content of the Greenlanders compared to that of the seals may reflect the length of the life span since the accumulation of $\mathrm{PCHC}$ is proportional to this value ${ }^{23}$. However, specific differences in the metabolic rates of turnover of PCHC may also be a determining factor. Compared to the PCB content of individuals living in industrial areas (below 1 p.p.m.) ${ }^{24}$ the Greenlanders seem to contain more PCB after longtime exposure, due, probably, to their trades as hunters and fishermen.

\section{REFERENCES}

${ }^{1}$ D. W. Anderson, J. J. Hickey, R. W. Risebrough, D. F. Hughes and R. E. Christensen. Canad. Field-Nat. 2, 91 (1969).

2 A. V. Holden and K. Marsden. Nature, London, 216, 1274 (1967).

3 A. V. Holden and K. Marsden. J. Chromatogr. 44, 481 (1969).

4 S. Jensen, A. G. Johnels, M. Olsson and G. Otterlind. Nature, London, 224, 247 (1969).

5 J. Maddox. Nature, London, 236, 433 (1972).

6 N. W. Moore and C. H. Walker. Nature, London, 201, 1072 (1964).

7 I. Prestt, D. J. Jefferies and N. W. Moore. Environ. Pollut. 1, 3 (1970).

8 R. W. Risebrough, P. Rieche, D. E. Peakall, S. G. Herman and M. N. Kirven. Nature, London, 220, 1098 (1968).

9 S. Ulfstrand and A. Södergren. Ambio, 1, 150 (1972).

10 L. Braestrup, J. Clausen and O. Berg. Bull. Environm. Contam. Toxicol. 11. 326 (1974).

11 J. Clausen, L. Braestrup and O. Berg. Bull. Environm. Contam. Toxicol. 12.529 (1974).

12 E. L. Delvaux. J. Pharm. Belg. 26, 475 (1971). 


\section{JØRGEN CLAUSEN AND OLE BERG}

13 A. V. Holden. Fisheries Improvement Committee Paper No. C.M. 22 (1968).

14 J. H. Koeman, M. C. Teh Noever De Brauw and R. D. De Vos. Nature, London, 221, 1126 (1969).

15 L. J. Blus, C. D. Gish, A. A. Belisle and R. M. Prouty. Nature, London, 235, 376 (1972).

16 J. M. Anderson and M. R. Peterson. Science, 164, 440 (1969).

17 D. M. Oglivie and J. M. Anderson. J. Fish. Res. Bd Canad. 22. 503 (1956).

18 H. H. Yap, D. Desaiah and L. K. Cutkomp. Nature, London, 233, 61 (1971).

19 J. L. Mosser, N. S. Fisher and C. F. Wurster. Science, 176, 533 (1972).

20 F. H. Premdas and J. M. Anderson. J. Fish. Res. Bd Canada, 20, 827 (1963).

21 J. Clausen and G. Konat. Experientia, 28, 902 (1972).

22 F. W. Braestrup. The Seals in Our Land's Wild Animals, p 99. Ed. F. W. Braestrup, G. Thomsen and E. Wesenberg-Lund. Gyldendal Ltd: Copenhagen (1949).

23 H. L. Harrison, O. L. Loncks, J. W. Mitchell, D. F. Parkhurst, C. R. Tracy, D. G. Atts and V. J. Yamacene. Science, 170, 503 (1970).

${ }^{24}$ R. Edwards. Chem. \& Ind. 1340 (20 November 1971). 